\title{
Economic value added (EVA) versus traditional tools in predicting corporate performance in Malaysia
}

\author{
Issham Ismail \\ School of Distance Education, Universiti Sains Malaysia.
}

Accepted 19 June, 2012

\begin{abstract}
A tool which could help in explaining company's performance, particularly in Malaysia, in terms of quantitative factor is very much needed. However, it is arguable if earnings alone can be considered as the best performance tool. Economic value added (EVA) has recently amazed much attention as a tool that takes into consideration many factors and incorporates more information as compared to traditional tools. This study discloses that EVA per share is able to correlate and had a better relationship with the stock return than traditional tools for public listed companies in Bursa Malaysia.
\end{abstract}

Key words: Economic value added (EVA), Malaysia, quantitative performance, stock return and traditional tool.

\section{INTRODUCTION}

Company performance can be measured by using various techniques. Company performance measurement can be a quantitative or qualitative characterisation of performance. Qualitative or non-financial measures such as internal coordination, the innovation process and brand image are said to be some of the most important qualitative performance factors of a company. These measures refer to a company's overall capability in producing quality activities, in a way that may lead to improvement in business performance.

Quantitative performance refers to physical measurement that enables investors to evaluate business activities through financial statements of the company. However, it is arguable if earnings or profit alone can be considered as the best performance tool. In an influential study, Stewart (1991) argued that accounting earnings fails to recognise the cost of capital and the riskiness of a firm's operations. Earnings, earnings per share (EPS) and earnings growth are misleading measures of corporate performance. As earning or EPS derived from accounting information can be easily manipulated. Users need performance measurement tools which combine the factors of economy, accounting and market information in its calculation.
Thus, a tool which could help in explaining or evaluating a company's performance, particularly in Malaysia, in terms of quantitative factor is very much needed, since quantitative data is easily measurable, tested and transparent and is readily available to investors and researchers. Such a performance tool is expected to assist interested parties in valuing the performance of companies.

From the review of performance measurement literature, economic value added (EVA) has recently amazed much attention as a tool that takes into consideration many factors. EVA incorporates more information as compared to traditional tools (that is EPS, dividend per share (DPS), net operating profit after tax (NOPAT) and earning). Stern Stewart Company has advocated that an economic value added (EVA ${ }^{\mathrm{TM}}$ ) should be used instead of earnings or cash from operations as a measure of both internal and external performance.

This study was undertaken with a view to identify the relationship between EVA and the company performance in Malaysia. It also sought to explain the ability of EVA as compared to traditional tool as performance measurement, while, the company performance can be represented by the stock return. 
The hypotheses of the study are H1: EVA per share is able to provide information in explaining the variation of stock return and H2: EVA per share is able to provide more information than traditional tools in explaining the variation of stock return.

\section{ECONOMIC VALUE ADDED (EVA) VERSUS TRADITIONAL TOOLS}

Binnersly (1996) notes that every company in the world measures performance and, increasingly, the debate is about what should be measured, how and by what. Many existing systems of performance measurement that have been designed are overseen by financial experts. Such systems have had a strong control bias and have limited input to the finance function. The traditional financial performance measures may have worked for the industrial era but are out of step with the skills and competencies companies are trying to master today. The business paradigm has changed increasingly on how businesses services are operated, relying on relationships among customers, suppliers and employees, and how their services are organised as processes rather than as functions. Measuring performance by itself has no meaning. Meaning can only be achieved through comparison, either against past performance, (which usually provides no true indication of future) or competitive position, or through benchmarking.

Traditional tools are lagging indicators which do not provide much insight into what must be done differently in future. Such measures often rely on labour-intensive internal accounting systems that feed the formulaic reporting requirements of regulators and accounting bodies, with the result that accounting measures play a limited role in management decision-making. For example, EPS or ROI do not measure future cashgenerating potential, but measures rather past performance. Profits can be manipulated by trading-off the future for the present, either by reducing investment or sacking staff. As a consequence, manager's trade-off the interests of shareholders, employees, customers, the community and the firm's long-term future for short-run profit (Binnersly, 1996).

Binnersly (1996) had criticised traditional measures and recommend it should give more consideration on what drives the numbers rather than the numbers themselves; they tend to reflect functions rather than processes; they are structured to fit the organisation rather than help to shape it; and they generate too much information and provide the wrong level of information to the wrong people.

Traditional accounting methods are often influenced by the subjective opinion of the accountant and this appears to be especially important in the analysis of profitability. As a consequence, managers can easily manipulate accounting performance measures (Dyl, 1989; GomezMejia and Balkin, 1992; Hunt, 1985; Jensen and Murphy,
1990; Verrecchia, 1986). EPS is simply raised by investing more capital in business. If the additional capital is equity (cash flow) then the EPS will rise if the rate of return of the invested capital is positive. If the additional capital is debt, then the EPS will rise if the rate of return of the invested capital is above the cost of debt.

The EVA ${ }^{T M}$ technique was developed in order to satisfy this need, and it has been widely adopted in the ' 90 s and has received much attention both in academic and practitioner publications (Biddle et al., 1997; Brickley et al., 1997). The measurement of value creation according to EVA has been used as a guide for investment decisions. It has also been claimed that EVA ${ }^{\mathrm{TM}}$ helps to improve firm performance, operating profits, cash flow measures, the cost of capital and the firm investment activity (Prober, 2000; Stewart, 1991). Stewart (1994) further suggest that EVA ${ }^{\mathrm{TM}}$ stands well out from the crowd as the single best measure of wealth creation on a contemporaneous basis and is almost $50 \%$ better than its closest accounting-based competitor (including EPS, $\mathrm{ROE}$ and $\mathrm{ROI}$ ) in explaining changes in shareholder wealth.

McClenahen (1998) similarly observes that traditional corporate performance measures are being relegated to second-class status as metrics such as EVA become management's primary tools. There has been the widespread adoption of EVA by security analysts since "instead of using a dividend discount approach, these models measure value from the point of view of the firms' capacity for ongoing wealth creation rather than simply wealth distribution" (Herzberg, 1998).

Machuga et al. (2002) said empirical research to date on the relative effectiveness of EVA and EPS as measures of firm performance for stock valuation has been mixed. In contrast to prior research, which primarily focuses on the correspondence of these measures with shareholder value and changes therein, they examine the relative effectiveness in predicting future earnings and their role in enhancing the accuracy of analysts' forecasts. Their results indicate that EVA contains information that is incremental to EPS in predicting future earnings. In addition, they find that despite this potential for EVA to add incremental value to analysts' forecasts of future earnings, analysts do not use the information in reported EVA appropriately, but appear rather to "overweight it".

However, some empirical studies have questioned the efficiency of EVA ${ }^{\mathrm{TM}}$. Fernandez (2001), using a representative sample of American and European firms based on data provided by Stern Stewart and Company, analysed the correlation between the market value added (MVA) and the EVA ${ }^{\mathrm{TM}}$, net operating profit after tax (NOPAT) and weighted average cost of capital (WACC). Fernandez observed a low (and sometimes negative) correlation between EVA ${ }^{\mathrm{TM}}$ and MVA and concluded that NOPAT and WACC present higher levels of correlation with the increase in the MVA. The results are in line with 
those obtained by Biddle et al. (1997) and Riceman et al. (2000). EVA is superior to accounting profits as a measure of value creation because it recognises the cost of capital and hence, the riskiness of a firm's operations (Lehn and Makhija, 1996). According to Stewart, EVA is the most important empirical link to MVA. The change in EVA explains $35 \%$ of the change in MVA, or seven times more than sales growth, while the change in earnings per share explains only about $3 \%$ of the change in MVA (Taub, 2003).

Binnersly (1996) further states that with increasingly sophisticated businesses demanding prompt increasingly complex measurements to be reported ever faster has created an additional problem of managing the data appropriately has become a major issue. The measures and model appropriate for one division may not fit another, resulting in a diverse set of management reports with only a few common key financial indicators across the organisation. This is in contrast to the traditional systems which tend to rely on a common format across all divisions and all areas of profit and loss responsibility.

However, Mäkeläinen (1998) claimed return on investment (ROI) or internal rate of return (IRR) are good performance measures but maximising rates of return will not increase shareholder returns. Mäkeläinen (1998) further stated that the tool ignores the requirement that rate of return should or must be as high as cost of capital. Return on equity (ROE) does not tell owners whether the company is creating wealth for shareholders or destroying it.

\section{RESEARCH METHODOLOGY}

This study attempts to identify which performance tool (EVA or traditional tools) is superior in developing the relationship with stock return and can EVA correlates with stock return.

Exploratory designs and correlational method have been chosen for this study since the purpose of the study is to explore the relationship of EVA and stock return against traditional tools and stock return.

The analysis will apply panel pool regression which is use time series and cross section analysis simultaneously. The findings on each performance tool and stock return is analysed at this level. This analysis tool is used since panel pool data regression able to take account for larger sample sizes and longer periods of study concurrently. The data analysed involve companies listed in Bursa Malaysia, Malaysia.

To test the hypothesis, the panel pool single and multiple regression with common and period specific coefficients least squares analysis with White's heteroskedasticity-consistent (corrected) variances and standard errors are used.

White (1980) has derived a heteroskedasticity consistent covariance matrix estimator which provides correct estimates of the coefficient covariances in the presence of heteroskedasticity of unknown form. The White covariance matrix is given by:

$$
\hat{\Sigma}_{W}=\frac{T}{T-k}\left(X^{\prime} X\right)^{-1}\left(\sum_{t=1}^{T} u_{t}^{2} x_{t} x_{t}{ }^{\prime}\right)\left(X^{\prime} X\right)^{-1},
$$

where is $T$ the number of observations, $k$ is the number of regressors and $U_{t}$ is the least squares residual.
The panel pool regression with common coefficients means that for one period of study, all the different year have the same value or common coefficient. In turn, for panel pool regression for period specific coefficients, the value of coefficients are different for each year even for the same one period of study, it has period specific coefficients. For this study both technique was used in studying the ability of performance tools in explaining the dependent variable (company performance that is stock return).

The panel data regression assumes slope coefficients are constant but the intercept varies across individuals. It assumes that time or yearly slopes are constant but companies intercept vary across each company. Statistical inference is conditional on the observed cross-sectional units in the sample (Gujarati, 2003). This process is called the fixed effects model (FEM) is widely used among econometricians as the best assumption when sample number is large and period of study is shorter.

The sample of the companies comprise companies listed in main board and second board of Bursa Malaysia (and which data available) over the period 1993 to 2002. A longitudinal study been chosen since the performance tools must be able to correlate with most companies listed in Bursa Malaysia and would be sufficient to monitor the relationship between EVA and traditional tools in explaining company performance.

\section{Calculation of economic value added (EVA)}

In this study, EVA is calculated based on Cordeiro and Kent $\mathrm{Jr}$ (2001) which is as follows:

EVA $=$ Net operating profit after tax (NOPAT) $-($ Weighted average cost of capital (WACC) X Invested capital).

where,

NOPAT $=$ Profit and Lost before tax + Interest expense - Income taxes - Tax shield on interest (Tax rate $X$ Interest expense)

and,

Invested capital $=$ Short term debt + Long term debt + Minority interest + Shareholders equity where,

WACC $=$ Cost of debt $X$ \{Total debt $/$ (Total debt + Company's market value of equity $(\mathrm{CMVE}))\} \times(1-\mathrm{Tax})+$ [Cost of Equity $\mathrm{X}\{$ (CMVE /( Total debt+ CMVE))\}]

where,

CMVE = Company's share price $\mathrm{X}$ Total shares outstanding.

where,

Market value of company $=$ CMVE + Total debt + Minority interest

where,

Cost of equity is calculated by using capital asset pricing model

\section{DATA ANALYSIS}

In the panel pool single regression with common coefficients analysis for period of 1993 to 2002 and 75 samples of companies are used. Based on Table 1, the 750 observations for ten (10) years period is used in the panel pool regression analysis. EVA per share significantly correlated with stock return and produced an 
Table 1. Panel pool regressions with common coefficients between EVA Per share and stock return for the year 1993 to 2002 for main board companies.

\begin{tabular}{|c|c|c|c|c|}
\hline \multicolumn{5}{|c|}{ Dependent variable: Return } \\
\hline \multicolumn{5}{|c|}{ White cross-section standard errors and covariance (d.f. corrected) } \\
\hline Variable & Coefficient & Standard error & t-Statistic & Probability \\
\hline $\mathrm{C}$ & 1.610254 & 0.013905 & 115.8048 & 0.0000 \\
\hline EVA & 0.076613 & 0.011871 & 6.453827 & 0.0000 \\
\hline R-squared & 0.211821 & F-statistic & & 19.86037 \\
\hline Adjusted R-squared & 0.201155 & Prob (F-statistic) & & 0.000000 \\
\hline
\end{tabular}

Table 2. Panel pool regressions with period specific coefficients between EVA per share and stock return for the year 1993 to 2002 for main board companies.

\begin{tabular}{lcccc}
\hline \multicolumn{5}{l}{ Dependent variable: Return } \\
\multicolumn{4}{l}{ White cross-section standard errors and covariance (d.f. corrected) } \\
\hline Variable & Coefficient & Standard error & t-Statistic & Probability \\
\hline C & 1.845112 & 0.322603 & 5.719457 & 0.0000 \\
1993--EVA_1993 & -0.362239 & 0.273992 & -1.322079 & 0.1866 \\
1994--EVA_1994 & 0.031080 & 0.194146 & 0.160084 & 0.8729 \\
1995--EVA_1995 & 0.102243 & 0.042872 & 2.384812 & 0.0173 \\
1996--EVA_1996 & 0.022939 & 0.042520 & 0.539496 & 0.5897 \\
1997--EVA_1997 & 0.170183 & 0.052427 & 3.246081 & 0.0012 \\
1998--EVA_1998 & 0.125861 & 0.048390 & 2.600971 & 0.0095 \\
1999--EVA_1999 & -0.053928 & 0.072991 & -0.738825 & 0.4603 \\
2000--EVA_2000 & -0.078856 & 0.104459 & -0.754893 & 0.4506 \\
2001--EVA_2001 & 0.091702 & 0.030683 & 2.988709 & 0.0029 \\
2002--EVA_2002 & 9.355038 & 10.11617 & 0.924760 & 0.3554 \\
R-squared & 0.257849 & F-statistic & & 13.34883 \\
Adjusted R-squared & 0.238533 & Prob (F-statistic) & & 0.000000 \\
\hline
\end{tabular}

Table 3. Panel pool multiple regressions with common coefficients between EVA per share and traditional tools with stock return for the year 1993 to 2002 for 75 main board companies.

\begin{tabular}{lcccc}
\hline \multicolumn{5}{l}{ Dependent variable: Return } \\
\multicolumn{4}{l}{ White cross-section standard errors and covariance (d.f. corrected) } \\
\hline Variable & Coefficient & Standard error & t-Statistic & Probability \\
\hline C & 1.602775 & 0.028291 & 56.65314 & 0.0000 \\
EVA & 0.064284 & 0.027801 & 2.312315 & 0.0210 \\
EPS & -0.002696 & 0.039421 & -0.068379 & 0.9455 \\
DPS & 0.087258 & 0.054695 & 1.595352 & 0.1111 \\
NOPAT & $-4.35 E-11$ & $4.06 E-11$ & -1.070827 & 0.2846 \\
R-squared & 0.175591 & F-statistic & & 12.05849 \\
Adjusted R-squared & 0.161029 & Prob (F-statistic) & & 0.000000 \\
\hline
\end{tabular}

adjusted $R^{2}$ of $20.11 \%$, while for panel pool single regression correlated with period specific coefficient in Table 2, it is found that EVA per share produced an adjusted $R^{2}$ of $23.85 \%$ and produced correlation coefficient $\beta$ of 0.10 for $1995,0.17$ for $1997,0.13$ for 1998 and 0.09 for 2001. Based on the aforementioned findings, the EVA is able to correlate and had a relationship with the stock return.

\section{Ten-year (1993 to 2002) period analysis: Main board companies}

Based on Table 3, the panel pool multiple regression analysis for period of 1993 to 2002 (that is 10 years) showed that only EVA per share is statistically significant at $p$-value $10 \%$ while EPS, DPS and NOPAT are not significant. EVA produced a positive coefficient cor 
Table 4. Panel pool single regressions with common coefficients between EVA per share and stock return for the year 1993 to 2002 for 75 main board companies.

\begin{tabular}{lcccc}
\hline \multicolumn{5}{l}{ Dependent variable: Return } \\
\multicolumn{4}{l}{ White cross-section standard errors and covariance (d.f. corrected) } \\
\hline Variable & Coefficient & Standard error & t-Statistic & Probability \\
\hline C & 1.610254 & 0.013905 & 115.8048 & 0.0000 \\
EVA & 0.076613 & 0.011871 & 6.453827 & 0.0000 \\
R-squared & 0.211821 & F-statistic & & 19.86037 \\
Adjusted R-squared & 0.201155 & Prob(F-statistic) & & 0.000000 \\
\hline
\end{tabular}

Table 5. Panel pool single regressions with common coefficients between EPS and stock return for the year 1993 to 2002 for main board companies.

\begin{tabular}{lcccc}
\hline \multicolumn{5}{l}{ Dependent variable: Return } \\
\multicolumn{4}{l}{ White cross-section standard errors and covariance (d.f. corrected) } \\
\hline Variable & Coefficient & Standard error & t-Statistic & Probability \\
\hline C & 1.568747 & 0.013800 & 113.6743 & 0.0000 \\
EPS & 0.084643 & 0.021438 & 3.948217 & 0.0001 \\
R-squared & 0.229457 & F-statistic & & 22.00645 \\
Adjusted R-squared & 0.219031 & Prob (F-statistic) & & 0.000000 \\
\hline
\end{tabular}

Table 6. Panel pool single regressions with common coefficients between DPS and stock return for the year 1993 to 2002 for 75 main board companies.

\begin{tabular}{lcccc}
\hline \multicolumn{4}{l}{ Dependent variable: Return } \\
\hline \multicolumn{4}{l}{ White cross-section standard errors and covariance (d.f. corrected) } \\
\hline Variable & Coefficient & Standard error & t-Statistic & Probability \\
\hline C & 1.573861 & 0.016133 & 97.55514 & 0.0000 \\
DPS & 0.159745 & 0.049886 & 3.202197 & 0.0014 \\
R-squared & 0.211196 & F-statistic & & 19.78612 \\
Adjusted R-squared & 0.200522 & Prob(F-statistic) & & 0.000000 \\
\hline
\end{tabular}

-relation $\beta$ of 0.064 . It can be concluded that in this analysis EVA is able to correlate with stock return while traditional tools fail to correlate with stock return and has a relationship with the stock return.

Based on the single panel pool regression with common coefficients analysis for the period between 1993 and 2002 (that is 10 years), EPS has a better relationship with stock return than EVA per share, DPS and NOPAT since out of the 750 pool observations, $21.90 \%$ of the variation in stock returns can be explained by the variability in EPS, meanwhile EVA per share, DPS and NOPAT can only explain 20.12, 20.05 and $17.19 \%$ respectively (Tables 4, 5, 6 and 7 ).

Based on the single panel pool regression with period specific coefficients analysis over the period 1993 to 2002 (that is 10 years), Based on Table 8, EVA per share had a better relationship with stock return than EPS (Table 9), DPS (Table 10) and NOPAT (Table 11).
$23.85 \%$ of the variation in stock returns can be explained by the variability in EVA per share while EPS, DPS and NOPAT can only explain 22.56, 22.22 and $21.19 \%$ respectively.

Thus the study found that for the period 1993 to 2002 for 75 main board companies comprise of 750 observations, EVA had a better relationship with the stock return for period specific coefficients analysis than traditional tools, while for common coefficients analysis, traditional tools are having slightly better relationship with the stock return as compared to EVA.

\section{Conclusions}

The results disclose that EVA per share is able to correlate and had a relationship with stock return. The finding is consistent with studies carried out by Lehn and 
Table 7. Panel pool single regressions with common coefficients between NOPAT and stock return for the year 1993 to 2002 for main 75 board companies.

\begin{tabular}{lcccc}
\hline \multicolumn{4}{l}{ Dependent variable: Return } \\
\hline \multicolumn{4}{l}{ White cross-section standard errors and covariance (d.f. corrected) } \\
\hline Variable & Coefficient & Standard error & t-Statistic & Probability \\
\hline C & 1.584020 & 0.015103 & 104.8805 & 0.0000 \\
NOPAT & $6.84 \mathrm{E}-11$ & $3.65 \mathrm{E}-11$ & 1.870654 & 0.0618 \\
R-squared & 0.182915 & F-statistic & & 16.54347 \\
Adjusted R-squared & 0.171858 & Prob(F-statistic) & & 0.000000 \\
\hline
\end{tabular}

Table 8. Panel pool single regressions with period specific coefficients between EVA per share and stock return for the year 1993 to 2002 for 75 main board companies.

\begin{tabular}{|c|c|c|c|c|}
\hline \multicolumn{5}{|c|}{ Dependent variable: Return } \\
\hline \multicolumn{5}{|c|}{ White cross-section standard errors and covariance (d.f. corrected) } \\
\hline Variable & Coefficient & Standard error & t-Statistic & Probability \\
\hline $\mathrm{C}$ & 1.845112 & 0.322603 & 5.719457 & 0.0000 \\
\hline 1993--EVA_1993 & -0.362239 & 0.273992 & -1.322079 & 0.1866 \\
\hline 1994--EVA_1994 & 0.031080 & 0.194146 & 0.160084 & 0.8729 \\
\hline 1995--EVA_1995 & 0.102243 & 0.042872 & 2.384812 & 0.0173 \\
\hline 1996--EVA_1996 & 0.022939 & 0.042520 & 0.539496 & 0.5897 \\
\hline 1997--EVA_1997 & 0.170183 & 0.052427 & 3.246081 & 0.0012 \\
\hline 1998--EVA_1998 & 0.125861 & 0.048390 & 2.600971 & 0.0095 \\
\hline 1999--EVA_1999 & -0.053928 & 0.072991 & -0.738825 & 0.4603 \\
\hline 2000--EVA_2000 & -0.078856 & 0.104459 & -0.754893 & 0.4506 \\
\hline 2001--EVA_2001 & 0.091702 & 0.030683 & 2.988709 & 0.0029 \\
\hline 2002--EVA_2002 & 9.355038 & 10.11617 & 0.924760 & 0.3554 \\
\hline R-squared & 0.257849 & F-statistic & & 13.34883 \\
\hline Adjusted R-squared & 0.238533 & Prob(F-statistic) & & 0.000000 \\
\hline
\end{tabular}

Table 9. Panel pool single regressions with period specific coefficients between EPS and stock return for the year 1993 to 2002 for 75 main board companies.

\begin{tabular}{|c|c|c|c|c|}
\hline \multicolumn{5}{|c|}{ Dependent variable: Return } \\
\hline \multicolumn{5}{|c|}{ White cross-section standard errors and covariance (d.f. corrected) } \\
\hline Variable & Coefficient & Standard error & t-Statistic & Probability \\
\hline $\mathrm{C}$ & 1.545392 & 0.112552 & 13.73044 & 0.0000 \\
\hline 1993--EPS_1993 & -1.430006 & 0.430804 & -3.319389 & 0.0009 \\
\hline 1994--EPS_1994 & -0.046305 & 0.313834 & -0.147546 & 0.8827 \\
\hline 1995--EPS_1995 & 0.195862 & 0.044203 & 4.430930 & 0.0000 \\
\hline 1996--EPS_1996 & 0.011514 & 0.055491 & 0.207488 & 0.8357 \\
\hline 1997--EPS_1997 & 0.102028 & 0.039122 & 2.607922 & 0.0093 \\
\hline 1998--EPS_1998 & 0.036708 & 0.067401 & 0.544618 & 0.5862 \\
\hline 1999--EPS_1999 & 0.108288 & 0.130585 & 0.829251 & 0.4072 \\
\hline 2000--EPS_2000 & -0.021965 & 0.083551 & -0.262897 & 0.7927 \\
\hline 2001--EPS_2001 & 0.072485 & 0.043926 & 1.650162 & 0.0993 \\
\hline 2002--EPS_2002 & 3.277868 & 4.400861 & 0.744824 & 0.4566 \\
\hline R-squared & 0.245271 & F-statistic & & 12.48604 \\
\hline Adjusted R-squared & 0.225627 & Prob(F-statistic) & & 0.000000 \\
\hline
\end{tabular}


Table 10. Panel pool single regressions with period specific coefficients between DPS and stock return for the year 1993 to 2002 for 75 main board companies.

\begin{tabular}{|c|c|c|c|c|}
\hline \multicolumn{5}{|c|}{ Dependent variable: RETURN } \\
\hline \multicolumn{5}{|c|}{ White cross-section standard errors and covariance (d.f. corrected) } \\
\hline Variable & Coefficient & Standard error & t-Statistic & Probability \\
\hline $\mathrm{C}$ & 2.040826 & 0.420241 & 4.856327 & 0.0000 \\
\hline 1993--DPS_1993 & -3.747966 & 1.412753 & -2.652952 & 0.0082 \\
\hline 1994--DPS_1994 & -1.026373 & 1.017356 & -1.008863 & 0.3134 \\
\hline 1995--DPS_1995 & 0.136878 & 0.015590 & 8.780095 & 0.0000 \\
\hline 1996--DPS_1996 & 0.087070 & 0.196369 & 0.443399 & 0.6576 \\
\hline 1997--DPS_1997 & 0.395918 & 0.167272 & 2.366906 & 0.0182 \\
\hline 1998--DPS_1998 & 0.167614 & 0.252816 & 0.662986 & 0.5075 \\
\hline 1999--DPS_1999 & -0.609265 & 0.405062 & -1.504128 & 0.1330 \\
\hline 2000--DPS_2000 & 0.048561 & 0.425424 & 0.114148 & 0.9092 \\
\hline 2001--DPS_2001 & 0.472147 & 0.217623 & 2.169569 & 0.0304 \\
\hline 2002--DPS_2002 & -55.01582 & 57.34206 & -0.959432 & 0.3377 \\
\hline R-squared & 0.241933 & F-statistic & & 12.26188 \\
\hline Adjusted R-squared & 0.222203 & Prob(F-statistic) & & 0.000000 \\
\hline
\end{tabular}

Table 11. Panel pool single regressions with period specific coefficients between NOPAT and stock return for the year 1993 to 2002 for 75 main board companies.

\begin{tabular}{|c|c|c|c|c|}
\hline \multicolumn{5}{|c|}{ Dependent variable: Return } \\
\hline \multicolumn{5}{|c|}{ White cross-section standard errors and covariance (d.f. corrected) } \\
\hline Variable & Coefficient & Standard error & t-Statistic & Probability \\
\hline C & 1.774776 & 0.180290 & 9.844015 & 0.0000 \\
\hline 1993--NOPAT_1993 & $-1.51 E-09$ & $7.00 \mathrm{E}-10$ & -2.154122 & 0.0316 \\
\hline 1994--NOPAT_1994 & $-7.72 E-10$ & 4.12E-10 & -1.874681 & 0.0612 \\
\hline 1995--NOPAT_1995 & $3.19 \mathrm{E}-10$ & $1.33 \mathrm{E}-10$ & 2.403216 & 0.0165 \\
\hline 1996--NOPAT_1996 & $-8.68 \mathrm{E}-11$ & $6.35 \mathrm{E}-11$ & -1.367646 & 0.1718 \\
\hline 1997--NOPAT_1997 & $1.42 \mathrm{E}-10$ & $9.11 \mathrm{E}-11$ & 1.563191 & 0.1184 \\
\hline 1998--NOPAT_1998 & $1.91 \mathrm{E}-11$ & $6.00 \mathrm{E}-11$ & 0.317972 & 0.7506 \\
\hline 1999--NOPAT_1999 & $3.92 \mathrm{E}-10$ & $3.56 \mathrm{E}-10$ & 1.102421 & 0.2706 \\
\hline 2000--NOPAT_2000 & $-1.73 E-10$ & $3.38 \mathrm{E}-10$ & -0.512158 & 0.6087 \\
\hline 2001--NOPAT_2001 & $1.06 \mathrm{E}-10$ & $5.50 \mathrm{E}-11$ & 1.931500 & 0.0538 \\
\hline 2002--NOPAT_2002 & $-1.69 E-08$ & $1.78 \mathrm{E}-08$ & -0.952074 & 0.3414 \\
\hline R-squared & 0.231866 & F-statistic & & 11.59766 \\
\hline Adjusted R-squared & 0.211874 & Prob(F-statistic) & & 0.000000 \\
\hline
\end{tabular}

Makhija (1996), Uyemura et al. (1996), Milunovich and Tsuei (1996), Turvey et al. (2000), Biddle et al. (1997), West and Worthington (2000), Eljelly and Alghurair (2001) and Isa and Lo (2004).

The next hypothesis makes comparisons between EVA and traditional tools in developing the relationship with stock return. The study found that EVA had a better relationship with the stock return than traditional tools for the main board companies listed in Bursa Malaysia for period 1993 to 2002 covering 75 companies which involves 750 observations. The study conclude that generally EVA had a better relationship with the stock return than traditional tools for main and second board companies listed in Bursa Malaysia in Malaysia. In summary, this study revealed that EVA had a better relationship with companies performance than traditional tools, in line with the finding of Lehn and Makhija (1996), Grant (1996), Uyemura et al. (1996), Milunovich and Tsuei (1996), Telaranta (1997), Turvey et al. (2000), Biddle et al. (1997), West and Worthington (2000), Eljelly and Alghurair (2001) and Isa and Lo (2004).

\section{REFERENCES}

Biddle GC, Bowen RM, Wallace JS (1997), Does EVA Beat Earnings? Evidence on Associations with Stock Returns and Firm Values, J. 
Account. Econ. 24(3):301-336

Binnersly M (1996). Do You Measure Up? Manag. Acct. Quart. 11:3235.

Brickley JA, Smith CW, Zimmerman JL (1997). Management Fads and Organizational Architecture. J. Corp. Fin. 10(2):24-39.

Cordeiro JJ, Kent Jr. DD (2001). Do EVA Adopters Outperform Their Industry Peers? Evidence from Security Analyst Earnings Forecasts. Am. Bus. Rev. 19(2):57-63.

Dyl EA (1989). Agency, Corporate Control and Accounting Methods: The LIFO FIFO Choice. Manag. Dec. Econ. 10: 141-145.

Eljelly AMA, Alghurair KS (2001). Performance Measures and Wealth Creation in an Emerging Market: The Case Of Saudi Arabia. Int. J. Commun. Manag. 11(3/4): 54-71.

Fernandez P (2001). EVA, Economic Profit and Cash Value Added do not Measure Shareholder Value Creation. IESE Res. Ppr. 453(2002). http://www.iese.edu/research/pdfs/DI-0453-E.pdf

Gomez-Mejia L, Balkin DB (1992). Compensation, Organizational Strategy and Firm Performance. Strategic Manag. J. 13(5):381-397.

Grant JL (1996). Foundations of EVA for Investment Managers. J. Port. Manag. 23(1):41-48.

Gujarati ND (2003). Basic Econometrics, 4th edition, McGraw Hill.

Herzberg MM (1998). Implementing EBO/EVA® analysis in stock selection. J. Inv. 7(1):45-53.

Hunt HG (1985). Potential Determinants of Corporate Inventory Accounting Decisions. J. Acct. Res. 23(Autumn):448-467.

Isa M, Lo W (2001). Economic Value-Added in the Malaysian Listed Companies: A Preliminary Evidence. Cap. Mark. Rev. 9(1\&2):83-89.

Jensen MC, Murphy KJ (1990). CEO Incentives: It's Not How Much You Pay, But How. Harv. Buss. Rev. pp. 138-153.

Lehn K, Makhija AK (1996). EVA and MVA as Performance Measures and Signals for Strategic Change. Strat. Leadersh. 24(3):34-38.

Machuga SM, Pfeiffer Jr. RJ, Verma K (2002). Economic Value Added, Future Accounting Earnings, and Financial Analysts' Earnings Per Share Forecasts. Rev. Quant. Fin. Acct. 18(1):59-73.

Mäkeläinen E (1998). Economic Value Added as a Management Tool. Helsinki Sc. Econ Buss. www.evanomics.com/download/Intro.pdf
Mcclenahen JS (1998). Accounting For Change. Ind. Week. 247(17):6367.

Milunovich S, Tsuei A (1996). EVA in the Computer Industry. J. Appl. Corp. Fin. 9(1):104-115.

Prober LM (2000). EVA: A Better Financial Reporting Tool. Penn. CPA J. 71(3):27-33.

Riceman S, Cahan S, Lal M (2000). Do Managers Perform Better under EVA Bonus System? SSRN Work Ppr. http://ssrn.com/abstract=242780

Stewart GB (1991). The Quest for Value: A Guide for Senior Managers. New York. NY: Harper Business.

Stewart GB (1994). EVA: Fact and Fantasy. J. Appl. Corp. Fin. 7(2):7184.

Taub S (2003). MVPs of MVA. CFO Mag. pp. 59-66.

Telaranta T (1997). On residual income variables and shareholder wealth creation. Master's Thesis. Helsinki Sc. Econ. Buss. Admin. Helsinki 1997.

Turvey S, Lake C, L Duren, van E, Sparling D (2000). The Relationship Between Economic Value Added and the Stock Market Performance of Agribusiness Firms. Agric. Bus. 16(4):399-416.

Uyemura DG, Kantor CC, Petit JM (1996). EVA For Banks: Value Creation, Risk Management, And Profitability Measurement. J. Appl. Corp. Fin. 9(2):94-109.

Verrecchia RE (1986). Managerial Discretion in the Choice Among Financial Reporting Alternatives. J. Acct. Econ. 9:175-184.

West T, Worthington A (2000). The Usefulness of Economic ValueAdded (EVA) and Its Components in the Australian Context http:zSzzSzafbc.banking.unsw.edu.auzSzafbc12zSzpaperszSzwest. pdf/the-usefulness-of-economic.pdf.

White H (1980). A Heteroskedasticity-Consistent Covariance Matrix and a Direct Test for Heteroskedasticity. Econometrica 48:817-818. 